\title{
External Ear Neoplasm
}

National Cancer Institute

\section{Source}

National Cancer Institute. External Ear Neoplasm. NCI Thesaurus. Code C4652.

A benign or malignant neoplasm that affects the external ear. Representative examples

include ceruminous adenoma, polyp, and carcinoma. 